\title{
Enzymatic and molecular characterisation of leucine aminopeptidase of Burkholderia pseudomallei
}

Siew Mun Liew ${ }^{1}$, Sun Tee Tay ${ }^{1 *}$ and Savithiri D Puthucheary ${ }^{1,2}$

\begin{abstract}
Background: Leucine aminopeptidase (LAP) has been known to be a housekeeping protease, DNA-binding protein and repressor or activator in the operon regulation of virulence-associated genes in several bacterial species. LAP activity was consistently detected in overnight cultures of Burkholderia pseudomallei, the causative agent of melioidosis and this enzyme was partially purified and characterised in this study. The intra- and inter-species nucleotide and deduced amino acid sequence variation of LAP encoding gene (pepA) was determined. A pepA/PCR-RFLP assay was designed to facilitate the identification of major LAP sequence types amongst clinical and environmental isolates of B. pseudomallei.

Results: LAP activity was detected in B. pseudomallei culture supernantants by zymographic analysis. Optimum activity was at $\mathrm{pH} 9$ and stable at $50^{\circ} \mathrm{C}$. Enhanced enzymatic activity was observed in the presence of metallic ions $\mathrm{Mg}^{2+}, \mathrm{Ca}^{2+}, \mathrm{Na}^{+}$and $\mathrm{K}^{+}$. LAP activity was inhibited by EDTA, 1,10-phenanthroline, amastatin, $\mathrm{Mn}^{2+}$ and $\mathrm{Zn}^{2+}$. Sequence analysis of the complete nucleotide and deduced amino acid sequences of LAP-encoding (pepA) gene showed close genetic relatedness to B. mallei (similarity 99.7\%/99.6\%), but not with B. thailandensis (96.4\%/96.4\%). Eight pepA sequence types were identified by comparison with a 596 bp DNA fragment encompassing central regions of the pepA gene. A pepA/PCR-RFLP was designed to differentiate pepA sequence types. Based on restriction analysis with Stul and Hincll enzymes of the amplified pepA gene, clinical and environmental isolates showed different predominant RFLP types. Type I was the most predominant type amongst $73.6 \%$ (67/91) of the clinical isolates, while Type II was predominant in 55.6\% (5/9) of the environmental isolates.

Conclusions: This study showed that LAP is a secretory product of B. pseudomallei with features similar to LAP of other organisms. Identification of major LAP sequence types of B. pseudomallei was made possible based on RFLP analysis of the pepA gene. The high LAP activity detected in both B. pseudomallei and B. thailandensis, suggests that LAP is probably a housekeeping enzyme rather than a virulence determinant.
\end{abstract}

Keywords: Leucine aminopeptidase, Burkholderia pseudomallei, PCR-RFLP

\section{Background}

Bacterial enzymes have been known to play a major role in the pathogenesis of Burkholderia pseudomallei, the causative agent of melioidosis. This bacterium is known to secrete a number of enzymes such as protease, catalase, peroxidase, superoxide dismutase, phosphatase and phospholipase C (lecithinase), which are said to contribute to the virulence of the organism [1,2].

\footnotetext{
* Correspondence: tayst@um.edu.my

${ }^{1}$ Department of Medical Microbiology, Faculty of Medicine, University of Malaya, 50603, Kuala Lumpur, Malaysia

Full list of author information is available at the end of the article
}

In our previous study [1], high levels of leucine aminopeptidase (LAP) enzymatic activity had been detected in both clinical and environmental isolates of B. pseudomallei, by APIZYM analysis (bioMérieux, Marcy l'Etoile, France). LAP which belongs to the peptidase M17 family, is involved in the processing and regular turnover of intracellular proteins by catalyzing the removal of unsubstituted $\mathrm{N}$-terminal amino acids from various peptides $[3,4]$. Besides proteolytic activities, this enzyme is also known to play an important role as a DNA-binding protein in Escherichia coli [5], and a repressor or activator in the operon regulation of virulence-associated genes in 
E. coli, Vibrio cholerae and Pseudomonas aeruginosa [6-8]. The LAP enzyme has been proposed as an immunoantigen for vaccination against Fasciola hepatica in sheep $[9,10]$ and a promising drug target for Helicobacter pylori infections [11].

As there has not been any study on LAP of $B$. pseudomallei, the objective of the present study was to characterise the LAP activity of B. pseudomallei and to examine the intra- and inter-species variation in the nucleotide and deduced amino acid sequences of the LAP encoding gene (pepA). A pepA/PCR-RFLP was designed to facilitate the identification of LAP sequence types and for possible differentiation of phenotypically identical B. pseudomallei isolates.

\section{Methods}

\section{Extraction of LAP}

One milliliter of an overnight-culture of B. pseudomallei NCTC 13178 (McFarland 3) was inoculated into 3 liters of $\mathrm{BHI}$ broth and incubated at $37^{\circ} \mathrm{C}$ for $72 \mathrm{~h}$ with constant agitation at $120 \mathrm{rpm}$ in a shaker (DAIKI SCIENCES Co., Ltd., Korea). The bacterial cells were removed by centrifugation at $4,500 \mathrm{rpm}$ for $30 \mathrm{~min}$ at $4{ }^{\circ} \mathrm{C}$, and the flow-through filtered using a $0.2 \mu \mathrm{m}$ polyethersulfone membrane (Sartorius Stedium Biotech, Germany). One part of the filtrate was mixed with 2 parts of cold saturated ammonium sulfate solution for $10 \mathrm{~min}$ with stirring, prior to centrifugation at $12,000 \mathrm{rpm}$ for $45 \mathrm{~min}$ at $4^{\circ} \mathrm{C}$. The precipitate was dissolved in cold $50 \mathrm{mM}$ Tris- $\mathrm{HCl}$ buffer ( $\mathrm{pH}$ 7.6). Desalting was performed using HiPrep 26/10 desalting column (GE Healthcare BioSciences, Sweden) coupled to a $\mathrm{AKTA}^{\mathrm{Tm}}$ explorer 100 system (GE Healthcare Bio-Sciences, Sweden). The eluent was concentrated using a Vivaspin 15R column (MWCO 5,000 molecular cut-off, Sartorius Stedium Biotech, Germany) by centrifugation at $6,000 \mathrm{~g}$. The protein concentration of the sample was determined by Quick Start $^{\mathrm{TM}}$ Bradford Protein Assay (Bio-Rad, US) using bovine serum albumin as the standard.

\section{Zymographic analysis}

Zymographic analysis was performed to detect the presence of LAP activity in the crude extract of $B$. pseudomallei NCTC 13178. The extract was diluted 40 fold $(0.64 \mathrm{mg} / \mathrm{ml})$ and mixed with NativePAGE ${ }^{\mathrm{TM}}$ buffer $(4 \mathrm{X})$ (Invitrogen Corporation, Carlsbad) in a ratio of 3:1. The sample was analysed by native polyacrylamide gel electrophoresis (PAGE) using a one mm-thick gel $(10 \times 7.5 \mathrm{~cm}, 4 \%$ stacking gel and $8 \%$ resolving gel) in a Mini-PROTEAN ${ }^{\circ}$ Tetra Cell (Bio-Rad Laboratories, US) PAGE apparatus at $90 \mathrm{~V}$ for $120 \mathrm{~min}$. The gel was incubated at $37^{\circ} \mathrm{C}$ for $10 \mathrm{~min}$ in $50 \mathrm{mM}$ Tris- $\mathrm{HCl}$ buffer $(\mathrm{pH} 8.0)$ containing $0.5 \mathrm{mM} \mathrm{MgCl} 2$ and $200 \mu \mathrm{M}$ L-leucine-7amido-4-methylcoumarin $\bullet \mathrm{HCl}$ (Sigma Chemical Co.,
USA) dissolved in $0.5 \mathrm{ml}$ acetone [12]. Five microliters of $20 \mathrm{X}$ aminopeptidase I from Streptomyces griseus (Sigma Chemical Co., USA) was used as positive control for LAP. A fluorescent band similar to the control, representing LAP activity was visualised under UV light and photographed.

\section{Enzymatic characterisation}

LAP activity of the crude extract was quantitated as described by Wahid et al. [13]. Eighty microliters of the extract was added to $20 \mu \mathrm{l}$ of $10 \mathrm{mM}$ L-leucine-pnitroanilide substrate solution (Sigma Chemical Co., USA) and $100 \mu$ l of $50 \mathrm{mM}$ Tris- $\mathrm{HCl}$ buffer ( $\mathrm{pH} 7.6)$ in a microtiter well, followed by incubation at $37^{\circ} \mathrm{C}$ for $2 \mathrm{~h}$. The reaction was stopped by cooling the mixture on ice for $10 \mathrm{~min}$ and the optical density at $405 \mathrm{~nm}$ was measured using a microplate reader (Rayto Life and Analytical Sciences Co., Ltd., China). The LAP activity was quantitated by using a L-leucine-p-nitroaniline ( $p$-NA) calibration curve and defined as nanomoles of $p$-NA released per minute per milliliter of sample under the assay conditions.

The optimum $\mathrm{pH}$ for LAP activity was determined by incubating $80 \mu \mathrm{l}$ of the concentrated bacterial extract with $100 \mu \mathrm{l}$ of $50 \mathrm{mM}$ buffer solutions prepared at various pHs: 6.0-7.0 (sodium phosphate buffer), 7.0-9.0 (Tris- $\mathrm{HCl}$ buffer), 9.0-11.0 (carbonate buffer) and 11.0-13.0 (glycine buffer). Eighty microliters of the concentrated crude extract was mixed thoroughly with $100 \mu$ l buffer of various $\mathrm{pH}$ in a microtiter well at $30^{\circ} \mathrm{C}$ for $10 \mathrm{~min}$, before addition of $20 \mu \mathrm{l}$ of substrate solution. The mixtures were incubated at $37^{\circ} \mathrm{C}$ for $2 \mathrm{~h}$ and the LAP activity was determined as described above.

Table 1 Effect of metallic ions and inhibitors on LAP activity of B. pseudomallei NCTC 13178

\begin{tabular}{ccc}
\hline Compound & Concentration & $\begin{array}{c}\text { Relative } \\
\text { activity (\%) }\end{array}$ \\
\hline Control & $10 \mathrm{mM}$ & 100 \\
$\mathrm{Mn}^{2+}$ & $10 \mathrm{mM}$ & 52.2 \\
$\mathrm{Zn}^{2+}$ & $10 \mathrm{mM}$ & 42.8 \\
$\mathrm{Ca}^{2+}$ & $10 \mathrm{mM}$ & 126.0 \\
$\mathrm{Mg}^{2+}$ & $10 \mathrm{mM}$ & 135.8 \\
$\mathrm{~K}^{+}$ & $10 \mathrm{mM}$ & 107.2 \\
$\mathrm{Na}^{+}$ & $2 \mathrm{mM}$ & 118.0 \\
EDTA & $10 \mathrm{mM}$ & 0 \\
& $2 \mathrm{mM}$ & 0 \\
1,10-phenanthroline & $10 \mathrm{mM}$ & 0 \\
& $2 \mathrm{mM}$ & 69.9 \\
Phenylmethylsulfonylfluoride (PMSF) & $10 \mathrm{mM}$ & 35.9 \\
& $2 \mathrm{mM}$ & 0 \\
\hline
\end{tabular}


Figure 1 Zymographic analysis of $B$. pseudomallei leucine aminopeptidase [12]. (8\% polyacrylamide gel, 8 V/cm, $120 \mathrm{~min}$.). Lane 1-commercial aminopeptidase I of Streptomyces griseus. Lane 2- concentrated crude extract of B. pseudomallei NCTC 13178; *figure prints in black and white.

The effect of temperature on LAP activity was studied by incubating for $2 \mathrm{~h}, 80 \mu \mathrm{l}$ of the concentrated bacterial extract with $100 \mu \mathrm{l}$ of $50 \mathrm{mM}$ Tris- $\mathrm{HCl}$ buffer ( $\mathrm{pH}$ 7.6) and $20 \mu \mathrm{l}$ of $10 \mathrm{mM}$ L-leucine-p-nitroanilide substrate solution at different temperatures $(8,15,20,30,37,40$, 50,60 and $80^{\circ} \mathrm{C}$ ). The effect of metallic ions and other inhibitors on the LAP activity was investigated by exposing $80 \mu \mathrm{l}$ of the extract to $10 \mu \mathrm{l}$ of solution containing metallic ions $\left(\mathrm{Mn}^{2+}, \mathrm{Zn}^{2+}, \mathrm{Ca}^{2+}, \mathrm{Mg}^{2+}, \mathrm{K}^{+}\right.$and $\left.\mathrm{Na}^{+}\right)$, ethylenediaminetetraacetic acid (EDTA) (Amresco Inc., USA), 1,10-phenanthroline (Sigma Chemical Co., USA), phenylmethylsulfonyl fluoride (PMSF) and amastatin (AppliChem GmbH, Germany) (Table 1) and $90 \mu \mathrm{l}$ of $50 \mathrm{mM}$ Tris- $\mathrm{HCl}$ buffer ( $\mathrm{pH}$ 7.6). Each mixture was pre-incubated at $30^{\circ} \mathrm{C}$ for $30 \mathrm{~min}$ before addition of $20 \mu \mathrm{l}$ of the substrate solution. Following further incubation at $37^{\circ} \mathrm{C}$ for $2 \mathrm{~h}$, the LAP activity of each reaction was determined as described above.

\section{Sequence determination and analysis of LAP gene}

PCR primers [pepA273-F (5' -TTTCAGCCAGAAAGCCT ACG-3') and pepA1202-R (5'-GAGAAGAGGCCGGTGT TGT-3')] were designed using computer software Primer3 (v.0.4.0) (http://frodo.wi.mit.edu/primer3/input.htm) and Tm calculation for oligos (BioMath Calculator, Promega) (http:// www.promega.com/a/apps/biomath/index.html?calc=tm) for amplification of a $930 \mathrm{bp}$ fragment encompassing the central region of the pepA gene, using sequences retrieved from B. pseudomallei reference strains: 1106a [GenBank: CP000572], K96243 [GenBank: BX571965], 668 [GenBank: CP000570], 1710b [GenBank: CP000124] and MSHR346 [GenBank: CP001408] and 17 different pulsotypes of $B$. pseudomallei from a previous study [14]. Pure colonies of $B$. pseudomallei on LB agar were suspended in $500 \mu \mathrm{l} \mathrm{MiliQ}$ water, heated to $100^{\circ} \mathrm{C}$ for $30 \mathrm{~min}$ and cooled in ice for $10 \mathrm{~min}$ before centrifugation at 13,000 rpm for $10 \mathrm{~min}$. The clear supernatants were used as DNA templates for amplification. Each PCR reaction was performed by preparing a $25 \mu \mathrm{l}$ reaction mixture containing $0.25 \mu \mathrm{M}$ of primers pepA273-F and pepA1202-R, $0.20 \mathrm{mM}$ of dNTP, $1.25 \mathrm{U} / \mu \mathrm{l}$ of DreamTaq ${ }^{\mathrm{TM}}$ DNA polymerase (Fermentas, Lithuania), 1 X DreamTaq ${ }^{\text {TM }}$ buffer, $16.63 \mu \mathrm{l}$ of $\mathrm{dH}_{2} \mathrm{O}$ and $5 \mu \mathrm{l}$ of template DNA. PCR conditions were: one cycle at $95.0^{\circ} \mathrm{C}$ for $5 \mathrm{~min}$, and 30 cycles at $95.0^{\circ} \mathrm{C}$ for $1 \mathrm{~min}$, $61.1^{\circ} \mathrm{C}$ for $30 \mathrm{~s}, 72.0^{\circ} \mathrm{C}$ for $1.5 \mathrm{~min}$, followed by one cycle of final extension at $72.0^{\circ} \mathrm{C}$ for $5 \mathrm{~min}$. The PCR products were purified using GeneAll ${ }^{\circ} \operatorname{Expin}^{\text {тм }}$ Combo GP (GeneAll Biotechnology, Korea) and sequenced using 
primers pepA273-F, pepA1202-R, pepA442-F (5' -TTC ACGCAGATGAAGAGCAG-3') and pepA1037-R (5' -T TCATGCTCGTGACGATGT-3') in an Applied Biosystems ABI3730XL automatic sequencer. The contigs of pepA gene sequences were assembled and edited using Geneious Pro 4.7.6 (available from http://www. geneious.com/) and aligned using Mega 4.0.2 software.

\section{RFLP analysis of LAP gene fragments}

A PCR-RFLP assay was designed based on the pepA sequences. A total of 91 randomly selected clinical isolates of $B$. pseudomallei from Malaysia and 9 environmental isolates (4 from Singapore and 5 from Thailand) and 5 B. thailandensis isolates were used. In Additional file 1: Table S1 shows the origins of the B. pseudomallei isolates. Partial fragments (596 bp) of pepA gene were amplified from each isolate using primers pepA442-F and pepA1037-R using PCR conditions as described above, except for a higher annealing temperature of $63.9^{\circ} \mathrm{C}$. The amplified products were purified and subjected to digestion using StuI followed by HincII restriction endonucleases (Fermentas, Lithuania). The RFLP products were analysed by non-denaturing PAGE using 12\% polyacrylamide gel and stained with $0.5 \mu \mathrm{g} / \mathrm{ml}$ ethidium bromide. An O'GeneRuler ${ }^{\mathrm{Tm}}$ Ultra Low Range DNA ladder (Fermentas, Lithuania) was used as molecular weight marker.

\section{Results and discussion}

The pepA gene of B. pseudomallei consists of 1512 nucleotides and encodes for 503 amino acids. The predicted molecular mass of the expressed protein was $52.7 \mathrm{kD}$ (Gene annotation). In the zymographic analysis, a fragment with fluorescent activity was observed in the native gel loaded with the concentrated culture supernatant of B. pseudomallei NCTC 13178 (Figure 1). The enzyme activity was detected in the culture supernatant, suggesting that LAP is a bacterial secretory product, detectable at temperatures ranging from $30^{\circ} \mathrm{C}$ to $60^{\circ} \mathrm{C}$ (Figure 2) and $\mathrm{pH}$ ranging from 7 to 11 (Figure 3). The optimal LAP activity was at $\mathrm{pH} 9$ and at $50^{\circ} \mathrm{C}$. High optimum temperature has been reported for other LAPs: i.e. $60^{\circ} \mathrm{C}$ for tomatoes, E. coli and swine [15] and $70^{\circ} \mathrm{C}$ for Arabidopsis [16], whereas the alkaline pH of LAP has been reported for organisms such as E. coli and Arabidopsis thaliana $[15,16]$. The alkaline $\mathrm{pH}$ is said to facilitate the interaction between unprotonated $\mathrm{N}$-terminus substrate and hydrophobic core of LAP in order to hydrolyse the substrate $[17,18]$. The optimum activity of LAP at high temperature and $\mathrm{pH}$ (as shown in this study) may be an essential factor for B. pseudomallei to be extremely adaptable in a wide variety of environments and able to survive during nutritional deprivation and exposure to high temperature [19].

The effects of metal ions and inhibitors on LAP activity are shown in Table 1. There was enhancement of LAP activity in the presence of metal ions, in the order of $\mathrm{Mg}^{2+}>\mathrm{Ca}^{2+}>\mathrm{Na}^{+}>\mathrm{K}^{+}$. This observation is in agreement with previous studies whereby a broad range of metal-ion dependence has been demonstrated by metalloaminopeptidases: i.e. $\mathrm{Mn}^{2+}$ by LAPs of E. coli [16], $\mathrm{Mn}^{2+}$ by human cytosolic aminopeptidase [20] and $\mathrm{Ca}^{2+}$ by Streptomyces griseus [21]. In contrast, EDTA, 1,10phenanthroline and amastatin inhibited LAP activity completely whereas $\mathrm{Mn}^{2+}$ and $\mathrm{Zn}^{2+}$ exhibited partial inhibitory effects (relative activities of $52.2 \%$ and $42.8 \%$ respectively). Inhibition by chelating agents (EDTA and 1,10 -phenanthroline) is common in animal, plant and prokaryotic LAPs [16,22-26]. The inhibitory effects exerted by the chelating agents are suggestive that the enzyme is a metalloprotease. Amastatin which mimics the LAP catalytic transition state, is a strong inhibitor of animal aminopeptidases [25]. Hence, inhibition of LAP activity by this specific aminopeptidase inhibitor- amastatin, confirmed the identity of this enzyme as an aminopeptidase, as also described for LAP of Streptomyces hygroscopicus

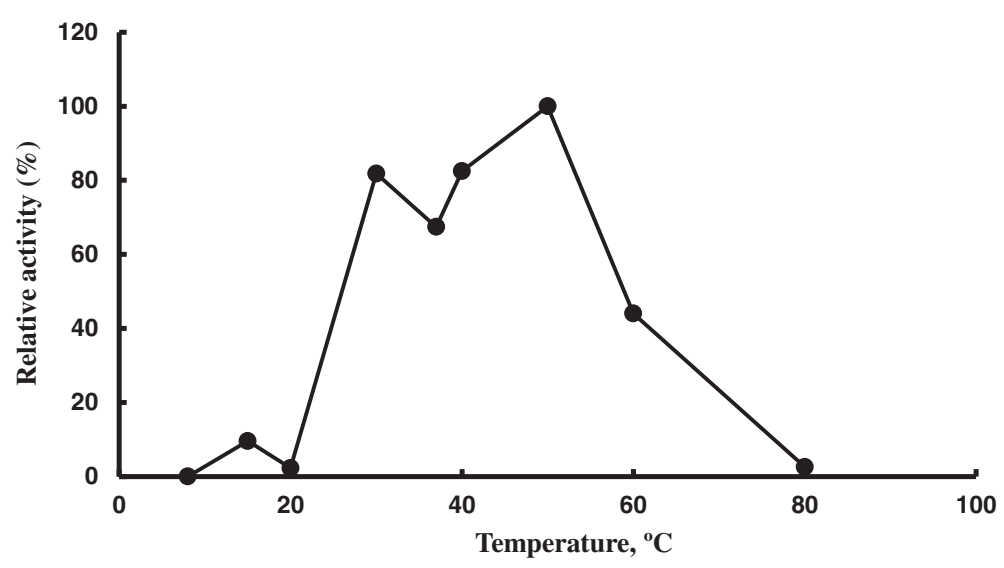

Figure 2 Effect of temperature on LAP activity of $\boldsymbol{B}$. pseudomallei NCTC 13178. (activities expressed relative to maximum value). 


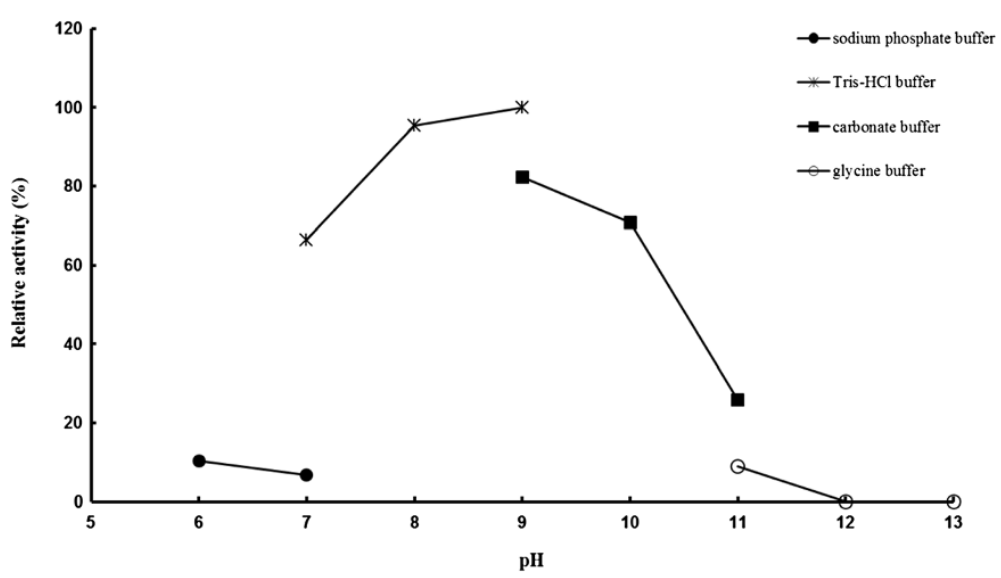

Figure 3 Effect of pH on LAP activity of B. pseudomallei NCTC 13178. (activities expressed relative to maximum value).

[23]. The LAP enzyme is probably not a serine protease as little impact was observed by the addition of serine protease inhibitor PMSF (only 30.1\% inhibition activity was observed in this study).

Comparison of the nucleotide sequences of the central region of the pepA gene (596 bp) of B. pseudomallei reference strains: 1106a [GenBank: CP000572], K96243 [GenBank: BX571965], 668 [GenBank: CP000570], 1710b [GenBank: CP000124] and MSHR346 [GenBank: CP001408] and 17 pulsotypes of Malaysian isolates of B. pseudomallei revealed 8 LAP sequence types (see Additional file 1: Table S2). Nucleotide polymorphism was found at 7 positions: 465, 549, 630, 665, 685, 897 and 952, of which two at positions 549 and 685 are being reported for the first time. Examination of the deduced amino acid sequences of the enzyme shows three amino acid differences, i.e. position 222 in B. pseudomallei MSHR346; position 229 in strain 69 and position 318 in B. pseudomallei 1710b, strains 28 and 57.

Five sequence types were identified from the 17 different pulsotypes representing the genetic diversity of B. pseudomallei isolates in Malaysia: the majority (11 isolates) were identical to B. pseudomallei strain 1106a, and 3 to B. pseudomallei strain 668. Three strains (BP57, BP69 and BP28) were new sequence types (see Additional file 1: Table S2) suggesting slight differences existed in the conserved pepA gene sequence between isolates from Malaysia and those in the GenBank database. (See Additional file 1: Table S3) shows the comparison of the nucleotide and deduced amino acid sequences of pepA gene of B. pseudomallei (K96243, 1710b and MSHR346) with the closely related species (B. mallei ATCC 23344, B. thailandendis E264 and B. oklahomensis EO 147). Between B. pseudomallei K96243 and B. thailandensis E264, there was only 96.4\% similarity in the nucleotide sequences. Comparison of 3 B. pseudomallei strains K96243, 1710b,
MSHR346 and B. mallei ATCC 23344 showed only one amino acid difference. However, comparison of B. pseudomallei strain K96243 with B. thailandensis and B. oklahomensis showed 15 amino acid differences.

Restriction analysis using StuI and HincII of the amplified pepA gene enabled the identification of 3 restriction fragment polymorphism patterns (assigned as type

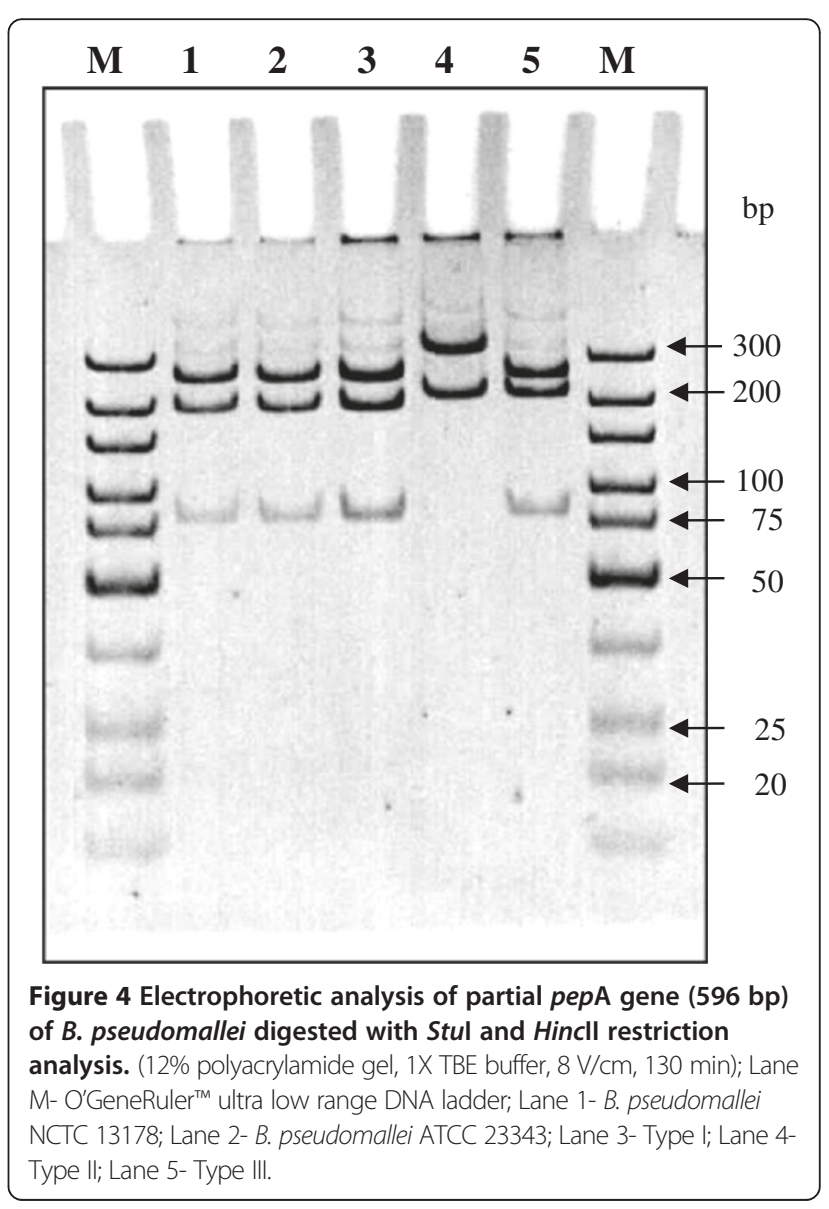


I to III) for B. pseudomallei: i.e. type I with fragments of 279, 213, 83 and $20 \mathrm{bp}$; type II with fragments of 362 and $233 \mathrm{bp}$ and type III with fragments of 279, 233 and 83 bp (Figure 4). Type I (73.6\%) and type II (55.6\%) pepA/RFLP types were predominant amongst our clinical and environmental isolates, respectively (see Additional file 1: Table S4).

\section{Conclusions}

To the best of our knowledge there are no published reports on the presence or characterization of LAP in B. pseudomallei. DNA sequencing of 17 different pulsotypes of B. pseudomallei isolates showed that the partial pepA gene sequence was highly conserved, with the detection of 2 extra intraspecific nucleotide divergences (not reported in the B. pseudomallei pepA gene sequences of GenBank). We describe here the characteristics of $B$. pseudomallei LAP: high optimum temperature $\left(50^{\circ} \mathrm{C}\right)$, alkaline optimum $\mathrm{pH}$ (ranging from $\mathrm{pH} 7.0$ to 10.0), requirement of divalent metal ions $\left(\mathrm{Mg}^{2+}, \mathrm{Ca}^{2+}, \mathrm{Mn}^{2+}\right.$ and $\left.\mathrm{Zn}^{2+}\right)$ for activity, and inhibition by LAP-specific inhibitors (EDTA, 1,10phenanthroline and amastatin) and some metal ions $\left(\mathrm{Mn}^{2+}\right.$ and $\left.\mathrm{Zn}^{2+}\right)$. The high LAP activity detected in both B. pseudomallei and B. thailandensis in both previous [1] and this study, suggests that LAP is probably a housekeeping enzyme rather than a virulence determinant. However, to verify whether LAP is truly a housekeeping gene, the use of a deletion mutant of LAP from B. pseudomallei will be needed. In addition, since iron is often correlated with virulence phenotypes, the effect of iron on the LAP activity should be determined. Further work to clone and express LAP as a recombinant protein is ongoing.

\section{Additional file}

Additional file 1: Table S1. Source and origin of clinical and environmental isolates of B.pseudomallei $(n=100)$. Table S2. Sequence types of the pepA gene of B. pseudomallei. Table S3. Comparison of nucleotide and deduced amino acid sequences of pepA genes of $B$. pseudomallei and closely related species. Table S4. PCR-RFLP of partial pepA gene (596 bp) of B. pseudomallei.

\footnotetext{
Abbreviations

LAP: Leucine aminopeptidase; pepA: LAP encoding gene; PCRRFLP: Polymerase chain reaction restriction fragment length polymorphism; PFGE: Pulse-field gel electrophoresis; $\mathrm{BHI}$ : Brain heart infusion; EDTA: Ethylenediaminetetraacetic acid; DNA: Deoxyribonucleic acid; APIZYM: Analytical Profile Index (ZYM); NCTC: National Collection of Type Cultures; ATCC: American Type Culture Collection; PAGE: Polyacrylamide gel electrophoresis; UV: Ultraviolet; p-NA: L-leucine-p-nitroaniline; PMSF: Phenylmethylsulfonyl fluoride; LB: Luria Bertani; dNTP: Deoxynucleotriphosphate; $\mathrm{dH}_{2} \mathrm{O}$ : Distilled water; bp: Base pair.
}

\section{Competing interests}

The authors declare that there is no conflict of interests.

\section{Authors' contributions}

This study was carried out as part of research work for Master of Medical Science degree. All authors read and approved the final manuscript.

\section{Acknowledgments}

This research was supported by the grants from the Short Term Research Fund (Vote-F) (FS198/2008B) and the Postgraduate Research Fund (PS164/ 2009B) from the University of Malaya. We wish to thank Prof. Surasakdi Wongkratanacheewin from Melioidosis Research Centre, Department of Microbiology, Faculty of Medicine, Khon Kaen University, Khon Kaen 4002, Thailand, Dr. E. H. Yap from Defense, Medical \& Environmental Research Institute, DSO National Laboratories, Republic of Singapore for providing $B$. pseudomallei environmental isolates, Mr. Mah Boon Geat and Mr. B. H. Chua from Axon Scientific Sdn. Bhd., Mr. Chang Teck Ming and Mr. Jason Lim from Interscience Sdn. Bhd., who have provided scientific expertise.

\section{Author details}

${ }^{1}$ Department of Medical Microbiology, Faculty of Medicine, University of Malaya, 50603, Kuala Lumpur, Malaysia. ${ }^{2}$ Medical Education, Research \& Evaluation Department, Duke-Nus Graduate Medical School Singapore, 8 College Road, Singapore 169857, Singapore.

Received: 28 November 2012 Accepted: 12 May 2013

Published: 17 May 2013

\section{References}

1. Liew SM, Tay ST, Wongratanacheewin S, Puthucheary SD: Enzymatic profiling of clinical and environmental isolates of Burkholderia pseudomallei. Trop Biomed 2012, 29(1):160-168.

2. Vellasamy KM, Vasu C, Puthucheary SD, Vadivelu J: Comparative analysis of extracellular enzymes and virulence exhibited by Burkholderia pseudomallei from different sources. Microb Pathog 2009, 47(3):111-117.

3. Miller CG: Protein degradation and proteolytic modification. In Escherichia coli and Salmonella typhimurium: Cellular and Molecular Biology. Edited by Neidhardt FC, Ingraham JL, Low KB, Magasanik B, Schaechter M, Umbarger HE. Washington, DC: American Society for Microbiology; 1987:680-691.

4. Yen C, Green L, Miller CG: Degradation of intracellular protein in Salmonella typhimurium peptidase mutants. J Mol Biol 1980, 143(1):21-33.

5. Stirling CJ, Colloms SD, Collins JF, Szatmari G, Sherratt DJ: xerB, an Escherichia coli gene required for plasmid ColE1 site-specific recombination, is identical to pepA, encoding aminopeptidase $A_{t}$ a protein with substantial similarity to bovine lens leucine aminopeptidase. EMBO J 1989, 8(5):1623-1627.

6. Behari J, Stagon L, Calderwood SB: pepA, a gene mediating $\mathrm{pH}$ regulation of virulence genes in Vibrio cholerae. J Bacteriol 2001, 183(1):178-188.

7. Charlier D, Hassanzadeh G, Kholti A, Gigot D, Pierard A, Glansdorff N: carP, involved in pyrimidine regulation of the Escherichia coli carbamoylphosphate synthetase operon encodes a sequence-specific DNA-binding protein identical to XerB and PepA, also required for resolution of ColEl multimers. J Mol Biol 1995, 250(4):392-406.

8. Woolwine SC, Wozniak DJ: Identification of an Escherichia coli pepA homolog and its involvement in suppression of the $\operatorname{alg} B$ phenotype in mucoid Pseudomonas aeruginosa. J Bacteriol 1999, 181(1):107-116.

9. Marcilla A, De la Rubia JE, Sotillo J, Bernal D, Carmona C, Villavicencio Z, Acosta D, Tort J, Bornay FJ, Esteban JG, Toledo R: Leucine aminopeptidase is an immunodominant antigen of Fasciola hepatica excretory and secretory products in human infections. Clin Vacc Immunol 2008, 15(1):95-100.

10. Piacenza L, Acosta D, Basmadjian I, Dalton JP, Carmona C: Vaccination with cathepsin $L$ proteinases and with leucine aminopeptidase induces high levels of protection against fascioliasis in sheep. Infect Immun 1999, 67(4):1954-1961.

11. Dong L, Cheng N, Wang MW, Zhang J, Shu C, Zhu DX: The leucyl aminopeptidase from Helicobacter pylori is an allosteric enzyme. Microbiol 2005, 151(6):2017-2023.

12. McCarthy E, Stack C, Donnelly SM, Doyle S, Mann VH, Brindley PJ, Stewart M, Day TA, Maule AG, Dalton JP: Leucine aminopeptidase of the human blood flukes, Schistosoma mansoni and Schistosoma japonicum. Int $J$ Parasitol 2004, 34(6):703-714.

13. Wahid MI, Bitoon SR, Fukunaga T, Yoshikawa T, Sakata T: Comparative study of leucine aminopeptidases from marine labyrinthulid and 
thraustochytrid strains. Mem Fac Fish. Kagoshima, Kagoshima University (Special Issue); 2008: 26-33. [http://hdl.handle.net/10232/7964].

14. Chua KH, See KH, Thong KL, Puthucheary SD: Spel restriction enzyme displays greater discriminatory power than Xbal enzyme does in a pulsed-field gel electrophoresis study on 146 clinical Burkholderia pseudomallei isolates. Japanese J Infect Dis 2011, 64(3):228-233.

15. Gu YQ, Holzer FM, Walling LL: Overexpression, purification and biochemical characterization of the wound-induced leucine aminopeptidase of tomato. Eur J Biochem 1999, 263(3):726-735.

16. Bartling D, Weiler EW: Leucine aminopeptidase from Arabidopsis thaliana. Molecular evidence for a phylogenetically conserved enzyme of protein turnover in higher plants. Eur J Biochem 1992, 205(1):425-431.

17. Andersson L, MacNeela J, Wolfenden R: Use of secondary isotope effects and varying $\mathrm{pH}$ to investigate the mode of binding of inhibitory amino aldehydes by leucine aminopeptidase. Biochem 1985, 24:330-333.

18. Kim H, Lipscomb WN: Structure and mechanism of bovine lens leucine aminopeptidase. Adv Enzymol Relat Areas Mol Biol 1994, 68:153-213.

19. Mahfouz ME, Grayson TH, Dance DA, Gilpin ML: Characterization of the mrgRS locus of the opportunistic pathogen Burkholderia pseudomallei: temperature regulates the expression of a two-component signal transduction system. BMC Microbiol 2006, 6:70.

20. Cottrell GS, Hooper NM, Turner AJ: Cloning, expression, and characterization of human cytosolic aminopeptidase $\mathrm{P}$ : a single manganese(II)-dependent enzyme. Biochem 2000, 39(49):15121-15128.

21. Spungin A, Blumberg S: Streptomyces griseus aminopeptidase is a calcium-activated zinc metalloprotein. Eur J Biochem 1989, 183:471-477.

22. Aoyagi T, Tobe H, Kojima F, Hamada M, Takeuchi T, Umezawa H: Amastatin, an inhibitor of aminopeptidase A, produced by actinomycetes. J Antibiot (Tokyo) 1978, 31(6):636-638.

23. Karadzic I, Izrael L, Gojgic-Cvijovic G, Vujcic Z: Leucine aminopeptidase from Streptomyces hygroscopicus is controlled by a low molecular weight inhibitor. J Biosci Bioeng 2002, 94(4):309-314.

24. Mohamed SA, El-Badry MO, Hamdy SM, Abdel-Ghany SS, Salah HA, Fahmy AS: Fasciola gigantica: purification and characterization of a leucine aminopeptidase. J App/ Sci Res 2009, 5(7):905-913 [http://www.aensiweb. com/jasr/jasr/2009/905-913.pdf].

25. Ogiwara N, Amano T, Satoh M, Shioi Y: Leucine aminopeptidase from etiolated barley seedlings: characterization and partial purification of isoforms. Plant Sci 2005, 168:575-581.

26. Pokharel DR, Rathaur S: Purification and characterization of a leucine aminopeptidase from the bovine filarial parasite Setaria cervi. Acta Trop 2008, 106(1):1-8.

doi:10.1186/1471-2180-13-110

Cite this article as: Liew et al.: Enzymatic and molecular characterisation of leucine aminopeptidase of Burkholderia pseudomallei. BMC

Microbiology 2013 13:110.

\section{Submit your next manuscript to BioMed Central and take full advantage of:}

- Convenient online submission

- Thorough peer review

- No space constraints or color figure charges

- Immediate publication on acceptance

- Inclusion in PubMed, CAS, Scopus and Google Scholar

- Research which is freely available for redistribution 